УДК 9(908)

DOI https://doi.org/10.24866/1997-2857/2021-2/51-64

\title{
X. Бёттхер*
}

\section{МАЛИНА И МЕДВЕДИ. О РАЦИОНЕ ИОГАННА КЕГЕЛЯ ВО ВРЕМЯ ЕГО ПУТЕШЕСТВИЙ ПО КАМЧАТКЕ (1841-1847 гг.)}

\begin{abstract}
Во время путешествия по полуострову Камчатка в начале XIX в. немецкий агроном Иоганн Карл Эренфрид Кегель (1784-1863) столкнулся с большими трудностями, одной из которых было обеспечение достаточного количества продовольствия. В данной статье на основе анализа путевых записок Кегеля рассматривается вопрос о том, как агроном добывал основные продукты питания и какие ресурсы при этом использовал. Исследование показывает, что, в зависимости от обстоятельств, Кегель либо покупал продовольствие у местных общин, либо полагался на товары, импортируемые торговыми судами, либо собирал дикие ягоды и охотился.
\end{abstract}

Ключевые слова: Иоганн Кегель, питание, Камчатка, Сибирь, экспедиция, инфраструктура

Berries and bears. On Johann Karl Ehrenfried Kegel's food supplies during his voyages in Kamchatka, 1841-1847. HENDRIK BÖTTCHER (University of Bonn)

Journeys through the Kamchatka peninsula in the early XIX ${ }^{\text {th }}$ century presented the German agronomist Johann Karl Ehrenfried Kegel (1784-1863) with great challenges. Among the most crucial was the securing of sufficient food supplies. Based on Kegel's travel journals, this article examines how he organized his provisions and which resources and infrastructure he made use of. It concludes that, depending on the circumstances, Kegel either drew on local communities' stocks, relied on goods imported by merchant ships, or gathered and hunted himself.

Keywords: Johann Kegel, provisions, food, Kamchatka, Siberia, expedition, infrastructure

\section{Введение}

В 1841-1847 гг. ${ }^{1}$ немецкий агроном Иоганн Карл Эренфрид Кегель (1784-1863) совершил поездку на восток Российской империи. Целью его путешествия было исследование природы

\footnotetext{
1 Даты в данной статье следуют григорианскому календарю. Сноски и ссылки, приводимые в конце абзаца, относятся ко всему абзацу и, если не указано иное, к цитатам, использованным в нем.
}

полуострова Камчатка. Отдаленность населенных пунктов, перебои с поставкой продуктов и холодный климат побережья Тихого океана существенно усложнили задачу Кегеля. Важным фактором успеха стала предприимчивость ученого, добывавшего пропитание в трудных природных условиях, и помощь местного населения, часто снабжавшего его продуктами. Данная статья имеет своей целью проанали-

* БЁТТХЕР Хендрик, младший научный сотрудник кафедры конституционной, социальной и экономической истории Университета Бонна (Германия).

E-mail: hboettch@uni-bonn.de

(C) Бёттхер X., 2021 
зировать рацион Иоганна Кегеля во время его путешествия по Камчатке. При этом основное внимание будет уделено не только составу его рациона, но и тому, как Кегель взаимодействовал с жителями полуострова для приобретения продовольствия.

Данное исследование базируется на отчете, составленном Кегелем о своей поездке, и двух дневниках, которые ученый вел, будучи на Камчатке. Эти дневники, среди прочего, описывают пребывание Кегеля в Мильково (1844-1845 гг.) и Петропавловске (1846 г.). Кегель, вероятно, написал свой отчет после возвращения в Одессу (1847 г.) на основе дневниковых записей. Этот отчет можно считать одним из самых подробных описаний полуострова Камчатка XIX в., однако до сих пор он редко служил основой для научных исследований. Будучи по профессии агрономом, Кегель был экспертом в вопросах питания, поэтому в своих трудах он сообщал необычайно подробную информацию о традиционной еде жителей Камчатки и о своем рационе. Наблюдения Кегеля позволяют по-новому взглянуть не только на инфраструктуру путешествий XIX в., но и на личность самого агронома, а также на экономические структуры Камчатки в исследуемый период. Отчет о поездке и дневниковые записи были впервые опубликованы в сборнике 2011 г. [13], что сделало возможным доступ к ним широкого круга читателей ${ }^{2}$. Количество второстепенных источников, посвященных личности Иоганна Кегеля и в целом режиму питания исследователей во время поездок в отдаленные районы в начале XIX в., ограничено ${ }^{3}$.

\section{На Дальнем Востоке России}

О жизни Кегеля известно немного. Он родился 3 октября 1784 г. во Фрисдорфе в Германии и сначала учился в Хальберштадте, затем в

2 Отчет о поездке, без дневников, был опубликован ранее, в 1992 г. Вернером Ф. Гюльденом под тем же названием.

3 Урсула Тимер-Заксе, например, исследовала питание немецкого географа Александра фон Гумбольдта (1769-1859) во время его поездки в Америку [29]. Вопросы логистики и рациона путешественников в научных исследованиях обычно упоминаются лишь вскользь; в контексте Камчатки, см., напр.: [28, p. 157-158]. О личности Кегеля, см. публикации Вернера Ф. Гюльдена и Эриха Кастена, данные в: [9, p. 11-14; 29, p. 77-83]. Доступ автора статьи к существующей русскоязычной литературе по исследуемой теме был ограничен. коммерческом колледже в Копенгагене (Дания). Будучи купцом, Кегель много путешествовал и в 1826 или 1827 гг. приехал в Россию. Поводом для этой поездки стал дядя его жены, Мельхиор Адам фон Мерц, служивший тогда при Государственном Совете Российской империи. Кегель жил сначала в Петербурге, затем в Саратове и Одессе. В ноябре 1840 г. Сибирский комитет принял решение послать эксперта для исследования полуострова Камчатка. Этот эксперт должен был в течение двух лет изучить возможности развития производства продуктов питания на полуострове и поддержать местное население в расширении сельского хозяйства. В первой половине XIX в. снабжение продуктами питания имело большое социальное значение: массовый голод был обычным явлением и нарушал не только экономическое развитие, но и политическую стабильность целых регионов. Более того, Камчатка была стратегически важна для российского правительства при Николае I. В долгосрочной перспективе полуостров должен был превратиться в оборонительный бастион России на востоке. Прогресс в этом направлении задерживался из-за того, что дальневосточные провинции были экономически неразвиты и зависели от дорогостоящих поставок продовольствия из других регионов. Решение этой проблемы, как считали эксперты того времени, могло быть достигнуто посредством укрепления местного сельского хозяйства ${ }^{4}$. Поэтому комитет поручил Иоганну Кегелю провести запланированное исследование, и весной 1841 г. он был отправлен в Сибирь [12, р. 207]

Камчатка к 1841 г. отнюдь не была неизведанной. С начала XVIII в. регион регулярно посещали корабли русских тихоокеанских экспедиций; позже кругосветные путешествия привели на полуостров таких исследователей, как Адельберт фон Хамиссо (1781-1838), Фёдор (Фридрих) Плениснер (ок. 1711 - ок. 1779) и Фридрих Генрих Фрейхер фон Киттлиц (1799-

4 В особенности сторонником идеи экономической автономии России был тогдашний министр финансов Егор Францевич Канкрин (1774-1845). Ожидаемое уменьшение трат государственной казны на поддержание региона было дополнительным стимулом для развития Камчатки. О Канкрине см., напр.: [31, р. 187$192]$.

${ }^{5}$ См.: [12, p. $207 ; 9$, p. 11,$13 ; 26$, p. 456; 25, p. 52, $55]$.

${ }^{6}$ Подробнее о нем см.: [2]. 
1874). На протяжении XIX в. все большее значение приобретало интенсивное освоение уже заселенных территорий, и путешественники все чаще пользовались разрастающейся инфраструктурой полуострова 7 .

В мае 1841 г. Кегель выехал из Петербурга на Урал; во время путешествия на Дальний Восток Кегеля сопровождали сменяющиеся попутчики. Чем больше он отдалялся от центра Российской империи, тем чаще его компаньонами становились местные проводники, помогавшие ему продвигаться по слаборазвитым маршрутам. В дальнейшем, уже на полуострове Камчатка, этот вид путешествий стал для Кегеля стандартным способом передвижения. Несмотря на дальнее расстояние, которое агроному требовалось преодолеть, он взял с собой большое количество продуктов, посуду и даже самовар [13, p. 32].

После тяжелого путешествия через Тобольск, Якутск и Охотск, а также кораблекрушения у западного побережья Камчатки, Кегель в декабре 1841 г. прибыл в Петропавловск. Здесь он перезимовал и следующим летом посетил центр и побережье полуострова. В 1842-1843 гг. Кегель исследовал север и запад Камчатки. В 1844 г. по просьбе администрации он попытался создать в деревне Мильково модельную ферму. Летом 1844 г. он отправился на крайний юг полуострова и, после повторного пребывания в Петропавловске, начал свой путь обратно в Европу в 1847 г. [13].

На Камчатке Кегелю пришлось адаптировать свой способ передвижения к особенностям местной инфраструктуры. В частности, значительно уменьшился объем его багажа. Большая часть исследований могла проводиться только в теплое время года, так как агроном стремился увидеть собственными глазами цветение местной флоры и процесс сельскохозяйственных работ; этот факт серьезно ограничивал свободу

\footnotetext{
${ }^{7}$ Среди наиболее крупных экспедиций стоит упомянуть, напр., первую и вторую Камчатские экспедиции (1728-1730 и 1733-1743 гг.), академическую экспедицию Петра Симона Палласа (1768-1774 гг.) и экспедиции Биллингса-Сарычева (1785-1795 гг.). См.: [3, p. 116-142; 30, p. 80-85]. Существуют также многочисленные упоминания о Камчатке, произведенные в этот период, в том числе Георгом Вильгельмом Стеллером, Отто фон Коцебу и Адельбертом фон Хамиссо. Выдержки из отчетов о поездках на Камчатку можно найти, напр., в: [15]; об исследовательских поездках см.: [2, с. 50; 24, р. 19-21]. В качестве примера освоения уже известных областей Сибири см. также информацию об экспедиции Александра фон Гумбольдта (1769-1859) в 1829 г. [9].
}

передвижений Кегеля по Камчатке. Зимой земля была промерзшей, и по ней легко было проехать на собачьих упряжках, но с началом лета полуостров превращался в кишащие комарами болота. Таяние снега в горах регулярно вызывало наводнения, которые часто делали дороги непроходимыми на несколько дней. Однако исследователь имел право полагаться на поддержку местного населения во время путешествий и часто пользовался им.

Зимой он передвигался на собачьих упряжках, летом - на лодке и лошадях. В отличие от путешествий по Западной Сибири, на Камчатке Кегель обычно не арендовал лошадей, а покупал и продавал их. Жители мест, которые Кегель посещал, сопровождали его на некоторых участках пути и служили ему проводниками. Кегель зависел от этих путеводителей, но оценивал их критически. Многочисленные служебные обязанности так обременяли людей, что они с трудом могли позаботиться о самих себе 8 .

Кегель часто оплачивал расходы из своей зарплаты, поскольку гарантированные дорожные деньги удерживались в течение длительного времени. В дороге он обычно ночевал в палатках или останавливался в деревнях. В некоторых населенных пунктах он проверял посевы, консультировал фермеров и пытался помочь в решении сельскохозяйственных проблем. Выводы о развитии сельского хозяйства на полуострове, к которым он пришел в конце поездки, были неутешительны: по мнению Кегеля, вместо того, чтобы обрабатывать поля, жители предпочитали охотиться на соболя и напиваться на вырученные от охоты деньги [13, p. 92-93, 121, 167-168].

Администрация Камчатки не только мало поддерживала агронома, но, как описывает это сам Кегель, пыталась максимально затруднить его работу. Причиной такого отношения к ученому стал конфликт, существовавший между реформистским российским правительством и административными структурами в провинции. Особенно в отдаленных районах царской империи, в начале XIX в. - как это было и в XVIII в. - администрация была полна коррумпированными или некомпетентными чиновниками, которые прежде всего занимались собственным обогащением в течение срока своих

${ }^{8}$ Схожее наблюдение сделал и Фридрих Генрих фон Киттлиц, исследовавший как орнитолог внутренние районы Камчатки в 1828 г. [28, p. 151-155]. О служебных обязанностях см., напр.: [13, p. 105106]. 
полномочий и отвергали любые изменения. Правительство пыталось противостоять этому путем частых ревизий и контроля [11, р. 775776; 10, p. 100-114; 13, р. 199-202].

Кегель отказывался покрывать упущения тогдашнего начальника Камчатки, Николая Василевича Страннолюбского (1802-1846) ${ }^{9}$, и поэтому в глазах местной администрацией был очередным малоприятным ревизором. Решения администрации не раз создавали опасные для жизни ученого ситуации. Кегель, в свою очередь, не пожалел критики в адрес Страннолюбского и в своих записях отметил, что место этого «подлеца» («Schuft») ${ }^{10}$ было не в администрации, а в шахте [13, p. 339; 3, p. 13].

\section{Гость на Камчатке}

Во время путешествий по Камчатке Кегелю приходилось регулярно приспосабливать свой рацион питания к сложившимся обстоятельствам. Далее мы рассмотрим три основных источника продовольствия, на которые агроном полагался во время своего путешествия.

Помощь местного населения не ограничивалась только транспортными услугами. Часто Кегель ночевал в деревнях, которые он посещал во время путешествий. Хозяева домов, в которых он останавливался, были в основном главами поселений или богатыми фермерами и купцами. Его часто угощали традиционной местной едой; Кегель всегда с интересом изучал особенности традиционной кухни и описывал в своем дневнике важные для отдельного поселения продукты. Блюда различались в зависимости от географического расположения поселений и этнических групп, проживавших в них. Кегель был чаще всего гостем в русских, камчадальских $^{11}$ и корякских ${ }^{12}$ селениях. Там

${ }^{9}$ Николай Васильевич Страннолюбский, капитан 1 ранга, командовал морской администрацией в г. Петропавловск. В своих отчетах Кегель обычно называет его только «шефом» («Chef»). Во время пребывания Кегеля на Камчатке Страннолюбский был заменен в должности. В 1850 г. на Камчатке был назначен отдельный губернатор [12, p. 208; 9, p. 11].

10 Здесь и далее перевод с немецкого автора статьи.

${ }^{11} \mathrm{~K}$ «камчадалам» Кегель относит как ительменов, так и смешанное население, образовавшееся в результате браков между ительменами и русскими, см.: [13, p. 94, 183]. В данной статье мы придерживаемся этого определения.

12 Под «коряками» здесь понимается коренной народ, проживающий на севере полуострова и ведущий частично кочевой образ жизни. См., напр.: [3, p. 87-88]. ему предлагали мясные и молочные блюда, рыбу, овощи, а также алкогольные напитки. За помощь и предложенную еду он обычно отвечал подарками; часто это были чай, сахар и другие труднодоступные продукты ${ }^{13}$.

Мясо и молочные продукты в деревнях не всегда были в достатке из-за небольшого поголовья скота на Камчатке. Основным препятствием для содержания крупного рогатого скота, а также свиней и кур, было бесчисленное количество собак в поселениях. Собаки были незаменимы для передвижения зимой на санях, но в то же время представляли опасность для молодняка сельскохозяйственных животных. Зимой 1842/1843 г. Кегель обнаружил, что собаки были «очень опасны даже для маленьких детей, двоих из которых [псы] разорвали и съели в Петропавловске» («Denn sie zerreißen und verzehren alles und sind selbst für kleine Kinder sehr gefährlich, wovon sie in Peterpaulshafen zwei zerrissen und verzehrt haben») [13, p. 86-89, 166].

Даже в таких крупных селениях, как Петропавловск, Кегель испытывал сложности в покупке продуктов. Непосредственно в этом городе упомянутый ранее капитан Страннолюбский получил право преимущественной покупки мяса, доставляемого в Петропавловск, и поэтому контролировал местную торговлю. Из-за плохих отношений с администрацией исследователь был ограничен в снабжении [13, p. 166].

Однако Кегель любил есть мясо и надеялся, что этот продукт, помимо прочего, улучшит его слабое здоровье. Поэтому он не упускал возможности приобрести мясо оленей, стада которых обычно паслись вдали от деревень. В частности, у коряков, живущих преимущественно в горах, были стада северных оленей; но даже у них Кегелю не всегда удавалось разнообразить свой рацион мясом: «Коряки готовят с кровью все содержимое желудка [оленя], и считают такую пищу вкусной и полезной. Нужен хороший аппетит [чтобы есть такое]» («Die Korjaken kochen aber den ganzen Inhalt des Magens mit dem Blut und finden das Essen daraus gut und gesund; freilich ein eigener Appetit gehört schon dazu») [13, p. 146 $]^{14}$.

13 Особенно славились своим гостеприимством камчадалы. Более критично Кегель относился к русским деревням, в которых часто селились ссыльные преступники. См., напр.: [13, p. 103, 130, 174]. О ссыльных на Камчатке см.: [6, p. 168-169, 184]; о гостеприимстве камчадалов см. отчеты Крузенштерна и Киттлитца в: [18, p. 104; 28, p. 157].

${ }^{14}$ См. также: [13, p. 81]. 
Отсутствие домашнего скота и птицы также сказывалось на доступности молочных продуктов и яиц. В частности, большой редкостью было сливочное масло, и Кегель чрезвычайно сожалел об этом. В своей заметке о селе Авача под Петропавловском он отметил: «Свежее масло, сыр и яйца полностью отсутствуют. Изза нехватки скота в этом районе, как и на всей Камчатке, эту продукцию невозможно поставлять из [близлежащих селений]. Масло поставляется из Якутска, и небольшое количество яиц привозят с островов» («Frische Butter, Käse, Eier fehlen gänzlich. Wegen des Mangels an Vieh in der Nähe - wie überhaupt in ganz Kamtschatka können diese Produkte nicht aus dem Land geliefert werden. Die Butter wird aus Jakutsk und die wenigen Eier werden von den Inseln des Meeres geholt») $\left[13\right.$, p. 286 ${ }^{15}$. Поэтому он очень радовался, когда ему предлагали масло. О своем пребывании у жителей села Ключевское он писал, среди прочего: «В приготовлении молочных продуктов они настоящие мастера и, я бы сказал, превосходят в этом швейцарцев» ( «In der Bereitung der Milchspeisen sind sie wahre Meister und übertrefen, so möchte ich sagen und behaupten, die Schweizer») [13, p. 130 $]^{16}$.

Вместо мяса Кегель чаще всего ел рыбу. В многочисленных заметках он отмечает богатство полуострова различными видами рыб - от речных сортов, таких как форель и хариус, до лосося, который регулярно мигрирует из моря во внутренние воды. Рыба была основным видом пищи и для большинства жителей Камчатки. Летом ее вылавливали в больших количествах, в основном путем строительства заграждений на реках; затем улов сушили на зиму. Сушка происходила в темных и сухих помещениях, где рыбу вешали на длительное время. Если не было ветра, то запах рыбы мог быть нестерпимым. Так Кегель описывает свое пребывание в Караке на северо-востоке Камчатки в августе 1843 г.: «Привыкаешь к обычному, не совсем приятному, рыбному запаху. Но когда рыба гниет на жаре без ветра, вонь становится невыносимой. [...] Поразительно, но [местные] не страдают от мух, хотя их миллиарды, и рыба, которая сушится, полностью ими покрыта» («An den üblichen, nicht gerade angenehmen Fischgeruch gewöhnt man sich. Wenn aber die Fische bei Hitze

${ }^{15}$ В начале XIX в. транспортировка сливочного масла на большие расстояния была обычным делом, см.: [25, р. 57].

${ }^{16}$ См. также: [13, p. 78-79, 230]. ohne Wind in Fäulnis übergehen, ist der Gestank unerträglich. [...] Auffallenderweise wird man von Fliegen nicht geplagt, obwohl es Milliarden davon gibt und die aufgehangenen Fische davon ganz bedeckt sind») [13, p. 197-198] $]^{17}$.

Выбор способа приготовления рыбы не в последнюю очередь зависел от ее размера. Мелкую рыбу Кегель ел в основном в супах, приготовленных с щавелем или луком. Более крупную рыбу, такую как форель, жарили или варили, и ее часто ели с маринованными огурцами или молочными продуктами, такими как сыр и сливки. От регулярного употребления жирной рыбы у Кегеля развилось множество проблем со здоровьем. Помимо запора, он часто страдал от язв, которые не позволяли ему «сидеть или ездить верхом в течение недели» («Es traten Geschwüre auf, die mir über eine Woche weder Sitzen noch Reiten erlaubten») трудности, с которыми, по мнению Кегеля, сталкивается почти каждый чужеземец [13, p. 151]. Тот факт, что Кегель, несмотря на проблемы со здоровьем, по-прежнему регулярно ел рыбу в своих путешествиях, в основном объясняется отсутствием других продуктов [13, p. 105, 111, 114, 121, 129, 180-182].

По мнению Кегеля, питаться овощами было гораздо полезнее, чем рыбой, однако земледелие на Камчатке не всегда было плодотворным занятием из-за прохладного климата. Намного проще было собирать плоды дикорастущих растений. Кегель сообщает, среди прочего, о тушеных корнях калужницы и других болотных растений, но прежде всего - о различных лилиях, таких как рябчик камчатский (Fritillaria camtschatcensis). Камчадалы, в частности, собирали луковицы лилий или брали их из зимних запасов мышей. По словам Эриха Кастена, эта практика на Камчатке наблюдается и сегодня. Кегель ел дикие овощи как в супах, так и в качестве гарнира $[13$, р. 105, 114-115, 153-154; 12, p. 217$]^{18}$.

Но даже несмотря на тяжелые условия для земледелия, исследователь периодически получал овощи с огородов русских и камчадалов. Наиболее распространенными продуктами были картофель, корнеплоды, горох, фасоль, огурцы и капуста. Особенно ценной была ква-

${ }^{17}$ См. также: [13, p. 115, 121]. Джеймс Р. Гибсон и Эрих Кастен равным образом подчеркивают важность рыбы в рационе жителей Камчатки [7, p. 49; 12, p. 217].

${ }^{18}$ О луковицах см., в частности: [13, p. 207-208]. 
шеная капуста, которая помогала предотвратить симптомы дефицита витаминов зимой. Во время пребывания в Мильково Кегель смог значительно расширить доступный ему ассортимент овощей. Благодаря маленькому саду он наслаждался «обилием не только картофеля, но и красивой цветной капусты, савойской капусты, кудрявой капусты, кольраби, брюквы, корнеплодов, редьки, моркови, огурцов, дыни, артишоков, гороха и табака, а также прекрасного ячменя» («nicht allein einen Überfluss an schönstem Kohl und Kartoffeln in dem kleinen Hausgarten, sondern auch schönen Blumenkohl, Savoyer - und Braunkohl, Kohlrabi, Kohlrüben, Rüben, Rettiche, Möhren, Gurken, Melonen, Artischocken, Erbsen und Tabak, auch schöne Gerste») $[13, \text { p. 248 }]^{19}$.

Помимо рыбы, мяса и овощей, хозяева домов, где останавливался Кегель, часто предлагали ему различные алкогольные напитки, которые были широко распространены как на Камчатке, так и во всей Сибири. Алкоголь либо покупали у торговцев, либо производили сами. Кегель сообщает, среди прочего, о водке на основе очищенного и сушеного борщевика, а также о вине из рейнского региона, мадере, портвейне, шампанском, женевере и роме, которые попадали на Камчатку через морскую торговлю $[13 \text {, р. 111-112, 163-164, 249-250 }]^{20}$.

Во время своих путешествий по полуострову Кегель регулярно сталкивался с повсеместным употреблением алкоголя и его последствиями. Поэтому он решительно отказался от рома, мадеры и женевера. Тем не менее, в записях Кегеля есть указания на то, что даже он употреблял и возил с собой алкогольные напитки. В январе 1846 г. он отметил в своем дневнике, что вино в бутылке замерзло от холода. В другой раз он пожаловался на кражу, совершенную его попутчиком. Кегель писал, что этот попутчик якобы нашел немногочисленные спиртные напитки, предназначенные на всю поездку, открыл и опустошил часть из них, а часть раздал местным камчадалам, некоторые из которых тоже были пьяны («Er hatte meinen wenigen für die ganze Reise bestimmten Branntwein geöffnet und beinahe

${ }^{19}$ См. также: [13, p. 108, 117, 157, 371; 7, p. 49].

20 Цена на спиртные напитки упала в начале XIX в. в результате технологических достижений в производстве: картофель, зерно и, в частности, отходы сахарных заводов можно было дешево перерабатывать, а полученное спиртное отправлять на экспорт. См.: [21, p. 172-173; 19, p. 165]. gänzlich geleert, da er auch den Kamtschadalen, die ebenfalls zum Teil betrunken waren, ausgeteilt hatte») $[13, \text { p. 190 }]^{21}$.

\section{Личные запасы Кегеля}

Часть провианта Кегель возил с собой. Сюда входили продукты питания, которые, по его мнению, способствовали поддержанию сбалансированной диеты, но которые невозможно было найти в отдаленных регионах, или же они были доступны только по очень высокой цене. На Камчатке такого рода продуктами были базовые припасы: рис, мука и крупы, а также чай и сахар. Этот дополнительный паек был нужен не только в тех деревнях, где питались в основном рыбой, но и при пересечении безлюдных территорий; в последнем случае требовалось особенно много еды, так как поездка могла неожиданно затянуться ${ }^{22}$.

Кегель обычно брал с собой рис, крупу, муку, сухари и соль. Муку он транспортировал в легких кожаных мешках. Сухари заменяли быстро портящийся хлеб, на отсутствие которого Кегель регулярно жаловался. Крупа также имела долгий срок хранения и была легка в приготовлении. Количество перевозимых продуктов обычно превышало собственное нужды Кегеля, ибо ему часто приходилось кормить и своих попутчиков-проводников. Люди, у которых он гостил, также часто ожидали, что он поделится с ними своими припасами. Поэтому во время длительного пребывания в Апаче осенью 1845 г. он «очень хотел уехать, тем более что заканчивались мука, чай, сахар и рис» («sehnlichst abzureisen, umso mehr, da mein Mehl, Tee, Zucker und Reis zu Ende gingen») [13, p. 284] $]^{23}$.

Транспортировать эти продукты питания не всегда было легко. Кегель писал о своей поездке на север полуострова: «Во время сильного шторма дождь проникал во все; сахар таял, а крупа и рис разбухали» («Der Regen durchdrang bei dem heftigen Sturm alles, ließ selbst den Zucker schmelzen und Grütze, Reis und Mehl quellen») [13, p. 194]. Но иметь при себе припасы было необходимо. В своем отчете о поездке

21 Об отношении Кегеля к алкоголю см.: [13, p. $121,366,382,394]$.

${ }^{22}$ Кегелю часто приходилось сталкиваться с такого рода ситуациями; например, он заблудился в болотах в конце лета 1842 г. [13, p. 152]. См. также: [13, p. 121, 169, 194, 214].

${ }^{23}$ См. также: [13, p. 80, 95, 186, 245, 257-258, 324, $327 ; 7$, p. 50]. 
на южный конец полуострова он подчеркивает их важность: без дополнительной еды невозможна никакая поездка, «иначе точно умрешь с голоду» («man würde andernfalls verhungern») [13, p. 257].

Как Кегель добывал эти припасы, которые он брал с собой в дорогу? Из-за неразвитости местного сельского хозяйства Камчатка зависела от обширного импорта, особенно от поставок зерна, чая, сахара, табака и масла. Значительная часть необходимых товаров сначала вывозилась из глубин Сибири в Охотск, где их погружали на корабли вместе с добываемой с побережья солью. Затем в августе или сентябре корабли обычно отправлялись на Камчатку, заходили в несколько портов и оставались зимовать на полуострове. В июне следующего года они уходили, нагруженные мехами. Однако путь от Якутска до Охотска был плохо развит, расположение порта было неудобным, а имеющиеся корабли и моряки лишь частично подходили для регулярных рейсов. Нередки были случаи, когда суда сбивались с курса или не доходили до Камчатки по каким-либо другим причинам. Таким образом, Кегель мог удовлетворять только часть своих потребностей за счет импорта из Охотска ${ }^{24}$.

Другой вариант поставки продовольствия, который до сих пор мало учитывался в исследованиях, возник благодаря многочисленным иностранным судам, которые регулярно заходили в Петропавловск. Согласно описанию Кегеля, это были рыбаки, охотники на тюленей и китов из Германии, Франции, Скандинавии и Америки. В добавок к этому приходили также торговые суда из разных стран. О торговле в Петропавловске Кегель сообщает следующее: «Ежегодно из Америки приходят от одного до трех судов с товарами. Торгуют в основном промышленными изделиями всех видов, вином, мукой, соленым мясом, ветчиной, сухими и консервированными фруктами, английскими и американскими соусами, солениями, солью, английской глиняной посудой, китайским фарфором, стеклом и изделиями из него, сталью и металлическими изделиями, оружием, порохом и т.п. Взамен они получают деньги или инструкции в Петербург, свежего и малосоль-

${ }^{24}$ Кегель тоже достиг Камчатки, следуя этому маршруту, но потерпел кораблекрушение. Джеймс Р. Гибсон подробно описывает снабжение Камчатки из Якутска и Охотска [7, р. 47, 56-59, 102, 104 , 128-129]. ного лосося, а также дрова» («Von Amerika kommen alle Jahre ein bis drei Schiffe mit Waren. Ihr Absatz besteht aus Manufakturwaren aller Art, Wein, Mehl, Salzfleisch, Schinken, trockenen und eingemachten Früchten, englischen und amerikanischen Saucen, Pickles, Salz, englischem Steingut, chinesischem Porzellan, Glas und Glaswaren, Stahl - und Eisenwaren, Gewehre, Pulver und dergleichen mehr. Dafür empfangen sie Geld oder Anweisungen auf Petersburg, frische und gesalzene Lachsarten sowie Brennholz») [13, p. 167].

Рост американской торговли в северной части Тихого океана был неприятностью для российского правительства. Но для Кегеля это было удачей: он получал с этих кораблей значительную часть своей основной еды и других припасов и хвалил, в частности, американскую муку. Однако большинство моряков добирались до Петропавловска только к началу лета, когда исследователь часто уже покидал город, чтобы воспользоваться остатками снега для путешествий. Поэтому ему приходилось регулярно пользоваться запасами государственных складов или частных петропавловских торговцев, которые закупали свои припасы летом на кораблях и продавали их зимой по значительно более высоким ценам [13, p. 163-164, 354, 376, 393, 395, 403-404, 407] $]^{25}$.

Помимо основных продуктов питания Кегель также брал с собой в путешествия большое количество чая. Его важность ярко проявляется во многих ситуациях, в которых оказывался Кегель во время путешествий. Когда корабль Кегеля по прибытии на Камчатку сел на мель на рифе и грозил затонуть, исследователь сначала послал «на камбуз за горячей водой для чая слугу с самоваром, потому что все промокли и хотели выпить чего-нибудь теплого» («So schickten wir einen Diener mit dem Samowar zur Kombüse, um heißes Wasser für Tee zu besorgen, denn alle waren durchnässt und sehnten sich, etwas Warmes zu trinken») [13, p. 78]. Кегель, будучи в пути, пил чай в любое время дня, но чаще всего вечером. Как и во всей России, чай пользовался большой популярностью у жителей Камчатки. Они потреблял его в значительных количествах, не в последнюю очередь из-за особого способа заваривания. Кегель писал: «Людям очень нравится крепкий [чай], темно-коричневого цвета,

${ }^{25} \mathrm{O}$ конфликте, возникшем вокруг американской торговли в регионе, см.: [30, p. 115-116]. 
как темное пиво» («Man liebt ihn sehr stark in einer Farbe wie braunes Bier») $[13, \text { p. 173 }]^{26}$.

Привезенный чай служил не только предметом роскоши, но и средством обмена. Кегель иногда упоминал чай в одном ряду с деньгами, а также признавал его важность в качестве подарка для местных. Во время путешествий он пришел к выводу, что чай и сахар нужно брать с собой «в больших количествах, потому что камчадалы и русские их очень любят и ими угощают всех, кто приходит к ним в гости. [Существенные запасы чая и сахара] это единственный способ сохранить работоспособность, лояльность и послушность [местных]» («Теe und Zucker muss in großen Quantitäten mitgenommen werden, weil die Kamtschadalen und Russen diese außerordentlich lieben und alle, die hinzukommen, damit bewirtet werden. Nur dadurch erhält man sie dienstfreudig, treu und folgsam») [13, p. 169 $]^{27}$.

Кегель различал два сорта чая. Первый, т.н. «кирпичный», делался из прессованных чайных листьев; полученные блоки было легко транспортировать. Этот «кирпичный» чай был очень распространен в Сибири, но часто имел лишь удовлетворительное качество [13, р. 45, 253]. Качеством получше, но и более высоким в цене был так называемый «цветочный чай», который Кегель покупал при первой возможности. Под этим сортом Кегель, вероятно, понимал, чайные листья, приправленные цветами; такой вид чая, например, производился в Китае. Во время своих путешествий Кегель обычно перевозил чай в коробках $[13, \text { p. 45, 253] }]^{28}$.

Важнейшим источником снабжения этим сортом чая были купцы и корабли в Петропавловске [13, p. 34, 57]. Если чай привозили из Охотска, то он в основном поступал от русско-китайской торговли в Средней Азии: так, китайские торговцы завозили его в больших количествах через Кяхту и продавали на территории царской империи. Взамен Россия

${ }^{26}$ См. также: [13, p. 184, 277]. Фридрих фон Киттлиц тоже брал с собой чай в поездки по Камчатке в 1828 г., см.: [28, p. 158-159]. О чае в России см., в частности: [14, p. 132-132; 1].

${ }^{27}$ О ценности чая как подарка см.: [13, p. 152, 324].

28 Люди, окружавшие Кегеля, также время от времени высказывали пренебрежительные комментарии по поводу «кирпичного» чая, см.: [13, р. 327, 331]. О цветочном чае см., напр.: [4, p. 148]. Пил ли Кегель в основном зеленый или черный чай, установить невозможно. Однако во время пребывания Кегеля на Камчатке, черный чай на мировом рынке имел лишь второстепенное значение, см.: [4, p. 133-136]. поставляла в Поднебесную, в частности, меха [16, p. $171-172 ; 14$, p. 132-132; 8, p. 125; 13, p. 34,57$]^{29}$.

Иностранные торговые суда, реализовывавшие чай на Камчатке, обычно закупали его непосредственно в Гуандуне. В частности, в десятилетия, предшествовавшие поездке Кегеля на полуостров, американские предприниматели сушественно увеличили свою долю в торговле чаем с Китаем. Цены на предметы роскоши на полуострове в целом были значительно выше, чем в Центральной Сибири. Например, Кегель заплатил от 12 до 18 руб. за фунт цветочного чая на Камчатке, что было почти вдвое больше суммы, которую он потратил на то же количество чая в Якутске. Дальнейшая транспортировка чая вглубь полуострова делала его еще дороже $[13 \text {, р. 83, 173, 284, 392; 14, р. 138-141 }]^{30}$.

При употреблении чая сахар был для Кегеля обязателен. Транспортировать его не всегда было легко из-за влажного климата. После нескольких дней непогоды на севере Камчатки Кегель писал: «К сожалению, из-за постоянного дождя [во время переправки на] байдарке ${ }^{31}$ и мокрых палаток все собранные мною растения были испорчены. Ибо если белые куски сахара вытекают из коробок в виде сиропа, все портится» («Leider waren mir bei dem ständigen Regen in der feuchten Baidara und den nassen Zelten schon alle gesammelten Pflanzen verdorben. Denn wenn schon der weiße Kandis als Sirup aus den Kisten läuft, lässt sich auch nichts anderes bewahren») [13, p. 196].

Кегель предпочитал покупать сахар в Петропавловском порту. Суда, пришвартованные там, поставляли почти исключительно тростниковый сахар. Значение другого сорта, свекловичного сахара, первоначально резко снизилось после окончания наполеоновской континентальной блокады; и хотя популярность его восстановилась впоследствии, процесс этот начался лишь незадолго до поездки Кегеля на Камчатку. Американские корабли, в частности, продавали тростниковый сахар из Карибского бассейна, который добывался там на больших плантациях, а затем очищался. Кегель возил с собой сахар в виде леденцов, так как крупные

${ }^{29}$ О торговле чаем через Кяхту см. также: [4, p. 675 676]; в частности, о ситуации в XVIII в. см.: [1].

${ }^{30}$ См. также: [10, p. 132-133]. Однако здесь стоит учесть тот факт, что цены в Якутске Кегель описывает как крайне низкие [13, p. 60].

${ }^{31}$ Небольшая лодка из моржовых шкур с восемью веслами, см.: [13, p. 193]. 
кристаллы были менее чувствительны к влаге, чем молотый сахар [22, p. 11-17; 21, p. 15-16, $172-175 ; 13$, р. $394 ; 27$, р. 31-36].

В дополнение к основной провизии, чаю и сахару, в путешествия Кегель брал с собой также некоторые продукты, произведенные в деревнях, особенно когда предстояла поездка по безлюдным местам. В отличие от путешествий по внутренней Сибири на Камчатке он не всегда мог запастись садовыми овощами или сушеным мясом ${ }^{32}$; вместо этого ему приходилось обходиться в основном сушеной рыбой, упомянутыми выше корнями калужницы болотной (Cáltha palústris) и небольшими лепешками из кипрея. Наличие этих лепешек было, по словам Кегеля, «удобно в поездке, так как эта еда очень сытная и живящая» («Sie sind sehr nahrhaft und - bloß getrocknet - auf der Reise angenehm, da diese Speise sehr sättigt und erfrischt») $[13, \text { p. 114] }]^{33}$.

\section{Дары природы}

Третий способ добычи пропитания, которым Кегель пользовался во время своего путешествия, - сбор дикорастущих растений и охота. Этим способом он пользовался довольно часто. Он и его группа не раз пересекали районы, опустошенные голодом; причина массового голода, по мнению Кегеля, крылась в высокой налоговой нагрузке, а также в нежелании местного населения заниматься земледелием. Более того, часто те припасы, которые Кегель имел при себе, портились из-за проливных дождей или жары. Агроном также иногда ошибался в своих расчетах и брал с собой слишком мало еды. Например, в конце лета 1842 г. он неожиданно вынужден был приостановить путешествие на несколько дней из-за непроходимых болот. Кегель писал: «Мои люди ели только вяленую рыбу, а у меня были с собой только чай и сахар, но не было ни чайника, ни кастрюли. Поскольку нормальный маршрут составляет всего 40 верст, при правильной организации, я взял с собой [чай и сахар] только в том количестве, которого достаточно, чтобы насладиться ими в деревне с Тоджоном и его семьей» («Meine Leute hatten nur einen Imbiss von trockenem Fisch, ich

${ }^{32}$ Во время путешествия по внутренним районам Сибири Кегель часто брал с собой полоски сушеной говядины. Переправляясь на Камчатку, он в основном ел соленое мясо, что было обычной пищей на корабле. См.: [13, p. 72, 80]. О соленом мясе см. также: [20, p. 88].

${ }^{33}$ См. также: $[13$, p. 55, 78, 152, 186]. aber nur Tee und Zucker, doch weder Kessel noch Kanne bei mir. Da die normale Strecke bei richtiger Führung nur 40 Werst lang ist, hatte ich nur dies mitgenommen, um es dort im Dorfe mit dem Tojon und seiner Familie zu genießen») [13, p. 152] $]^{34}$.

К счастью, пока Кегель искал путь через болота, он нашел, по крайней мере, большое количество ягод: «Смородина хотя бы избавила меня от сухости во рту, ибо болотная вода не годилась для питья» («Einige Johannisbeeren erfrischten wenigstens den trockenen Mund, da das Sumpfwasser für mich ungenießbar war») [13, p. 152]. Агроном питался ягодами в основном в тех случаях, когда не было другой еды. Например, когда ему пришлось ждать помощи на берегу в течение нескольких дней после кораблекрушения, а запасы, которые не были испорчены морской водой, заканчивались, он отправился на поиски диких ягод. Позже он писал об этом: «Я нашел клюкву, аронию [...], а также малину и плоды шиповника, похожие на маленькие яблоки сорта rosa kamtschadalis lor. purpurea [...]» («Ich fand Preiselbeeren, Zwergvogelbeeren, zweimal größer und besser, sowie Tschickschen, eine Himbeer-Art, auch Hagebutten gleich kleinen Äpfeln der, Rosa Kamtschadalis lor. purpurea', die nun auch die Weiber zum Sammeln aus den Zelten lockten») [13, p. 81].

Ягоды также были приятным дополнением к трапезе во время путешествий. Благодаря высокому содержанию витаминов они помогали предотвратить цингу, а также улучшить вкус еды. «Множество разновидностей прекрасных ягод, неизвестных в Европе», - писал Кегель проезжая через Сибирь, - «заменяют здесь фрукты» («Die vielen Sorten schöner in Europa unbekannter Beeren ersetzen dort das Obst») [13, p. 69]. Благодаря влажному климату на Камчатке всегда было много ягод, что Кегель неоднократно отмечал во время своих путешествий ${ }^{35}$.

Наравне с ягодами благодаря влажному климату здесь также хорошо произрастали многочисленные дикорастущие травы. Кегель ел

34 Тимер-Заксе считает, что Александр фон Гумбольдт также небрежно планировал свои запасы продовольствия для путешествий, чего нельзя сказать о научном оборудовании, которое он вез с собой. См.: [29, p. 78]. О голоде в регионе см., напр.: [13, p. 55, 59, $184,265,298]$. Одна верста соответствует 1066,8 м. Тоджон, упоминаемый Кегелем, был главой поселения, которое агроном хотел посетить [13, р. 417-418].

${ }^{35}$ См.: [13, p. 102, 144; 5, p. 133; 7, р. 53]. Среди местного населения полуострова ягоды также пользовались популярностью, см.: [28, р. 158]. 
крапиву, черемшу и кипрей. Из крапивы можно было приготовить суп или гарнир; черемшу употребляли в качестве салата к рыбным и мясным блюдам. Черемша была настолько популярна у камчадалов и русских из-за высокого содержания витаминов, что ее часто отправляли в Охотск. О свежих побегах кипрея Кегель писал: «Я варил их и ел, как спаржу. Из них получается действительно вкусное блюдо; поскольку [кипрей] растет во многих лесах Германии и России, там тоже стоит ввести [его в рацион]» («Ich benutzte sie gekocht wie Spargel. Das ist eine wahrhaft angenehme Speise, die, da sie in vielen Wäldern Deutschlands und Russlands wächst, es wohl wert ist, auch dort dazu verwendet zu werden») $[13, \text { p. 175 }]^{36}$.

Однако сбор ягод и дикорастущих растений был не единственным способом добывания пищи в условиях ее нехватки. Кегель писал о своем пребывании в голодающем селе Ука в июле 1843 г: «В долгом пути у нас закончилась еда. Чай всем нравился, но он не мог утолить голод. Хорошо, что у меня с собой были удочки, и мы могли ловить рыбу. Нам повезло. Мы быстро поймали более 20 крупных форелей и хариусов, что нас и спасло» («Auf dem weiten Weg waren uns die Lebensmittel ausgegangen. Der Tee war allen zwar angenehm, sättigte aber nicht den Hunger. So war es gut, dass ich Fischangeln bei mir hatte, sodass wir fischen konnten. Das Glück war uns hold. Schnell wurden über 20 große Forellen und Äschen gefangen, wodurch für den Augenblick aller Not abgeholfen war») [13, p. 186].

Помимо рыб многочисленные водоемы Камчатки предлагали и другие виды продуктов, пригодных в пищу. На берегах рек и на отдельных островах у побережья было множество гнезд с яйцами водоплавающих птиц, которые Кегель собирал и с удовольствием ел. Осенью 1845 г., когда его товарищи готовили тюленя в заливе Большерецка, исследователь, не любивший этот тип мяса, обнаружил «множество красивых съедобных мидий, которые хорошо утоляют голод» («Ich fand eine Menge schöner essbarer Muscheln, die hinreichend den Hunger stillten») $[13, \text { p. 278 }]^{37}$. В другой раз, когда они с проводником обнаружили пещеру с медвежьими запасами, они нашли в ней несколько центнеров китового сала, закопанного под камнями: «Мой

\footnotetext{
${ }^{36}$ См. также: [13, p. 115].

37 Благодаря нескольким заметкам из дневника Кегеля создается впечатление, что он не был большим любителем мяса тюленей и китов. См., напр.: [13, p. 82].
}

камчадалец был в восторге. Он почистил [сало], попробовал его на вкус и оценил его, как свежее и вкусное. Мы дождались наших товарищей изза медведей, которые могли все еще быть рядом. Затем часть сала была разрезана, упакована в кожаные мешки и возложена на лошадей» («Wir untersuchten nun sein Lager und fanden ein paar Zentner Walfischspeck unter Steinen verscharrt. Das bereitete meinem Kamtschadalen große Freude. Er reinigte denselben, kostete ihn und fand ihn frisch und gut. Da nichts verlorengehen sollte, warteten wir wegen der noch in der Nähe befindlichen Bären die Gefährten ab. Dann wurde ein Teil zerschnitten, in lederne Säcke gepackt und auf die Pferde gelegt») [13, p. 217 $]^{38}$.

Но и сам медведь мог стать добычей, особенно когда у путешественников не хватало запасов. Практическое отсутствие животноводства делало охоту на крупных диких животных особенно привлекательной для исследователя. Позже он писал о своей встрече с медведем осенью 1843 г. в местечке к северу от деревни Кавран: «Всего в нескольких сотнях шагов, над рекой, я увидел его, большого серого медведя, который, увидев меня, захотел уйти в лес; но я пустил пулю в переднюю часть его груди, затем без промедления другую, после чего медведь упал в воду и умер. Он был большим и толстым. Мне с напарником было очень неудобно вытаскивать его на берег, но из [мяса медведя] получилось хорошее жаркое на вечер. А из его шкуры мы сделали хороший ночлег» («Erst ein paar hundert Schritte weiter erblickte ich ihn unten im Tal über dem Fluss, einen großen grauen Bären, der als er mich sah, sich trollen wollte; doch gab ich ihm eine Kugel vorne in die Brust und dann schnell noch die zweite, nach der er ins Wasser fiel und endete. Er war ein großer, fetter Bursche. Es machte meinem Begleiter und mir sehr zu schafen, ihn ans Land zu ziehen, wo er abgezogen einen guten Braten für den Abend lieferte. Sein Fell bot ein gutes Nachtlager») [13, p. 218].

Кегель чаще всего ел мясо медведя в жаренном или вареном виде; иногда он ограничивался лишь излюбленными частями, например, печенью. Но охота на медведя не была безопасной, что следует из яркого описания Кегелем вечера после неудачного преследования: «Я подносил чашку ко рту, а мои люди ели, когда один из них, вставший, чтобы что-то достать, вдруг громко вскрикнул, схватил мой $[\ldots]$ пистолет и выстрелил из него. Мы все сразу же вскочили

${ }^{38}$ См. также: [13, p. 97, 133-134, 219]. 
и схватили винтовки. Теперь мы увидели движение тени. Всего в пяти шагах от нас стоял большой медведь и, вероятно, собирался атаковать нас, но выстрел и наше движение напугали его. Я никогда раньше не сталкивался с такой опасностью, но был рад, что благополучно пережил все это. Мы проверили каждую винтовку и провели беспокойную ночь с заряженными ружьями в руках» («Ich führte gerade die Teetasse zum Mund und meine Leute waren beim Essen, als einer von ihnen, der aufgestanden war, um etwas zu holen, laut aufschrie, meine Pistole, die noch am Hals hing, ergriff und abfeuerte. Wir anderen sprangen sofort auf und ergriffen die Gewehre. Nun sahen wir, wie sich ein Schatten bewegte. Ein großer Bär hatte nur 5 Schritt von uns entfernt gestanden und sich wahrscheinlich gerade entschlossen, uns anzufallen, als ihn die Kugel aus der Pistole und unser Aufspringen eines Besseren belehrte. Eine solche Gefahr hatte ich bisher noch nicht erlebt, doch glücklich überstanden. Wir sahen jedes Gewehr nach und verbrachten die Nacht etwas unruhig mit geladener Waffe im Arm») [13, p. 277] $]^{39}$.

Во время своих путешествий помимо медведей и уток Кегель также отстреливал гусей, глухарей, куропаток и даже чаек [13, p. 109 , $188,218,262]$. Заметки Кегеля не подтверждают предположение о том, что в некоторых районах Сибири чрезмерная охота привела к исчезновению отдельных видов животных и птиц. Напротив, говоря о районе между селами Шаромы и Верхнекамчатск, Кегель сообщает: «Во время речной прогулки у меня была возможность полюбоваться бесчисленным количеством диких уток всех цветов и размеров, а также запастись достаточным количеством мяса для ужина; здесь можно было застрелить тысячу птиц и даже не заметить уменьшения их количества» («Bei der Flussfahrt hatte ich Gelegenheit, die zahllosen wilden Enten in allen Farben und Größen $\mathrm{zu}$ bewundern, mich aber auch hinreichend mit Braten zu versehen; bloß als Jagdfahrt hätte man wohl an die tausend schießen können, ohne ein Abnehmen der Zahl feststellen zu können») [13, p. 106 $]^{40}$.

Дальнейшее описание этой же речной прогулки демонстрирует также недостатки охоты на диких птиц. Кегель пишет: «Из-за охоты мы сбились с графика; мои камчадалы подстрелили глухаря и прекрасную выдру, но чтобы до-

${ }^{39}$ О пищевых привычках Кегеля см.: [13, p. 221, 266].

${ }^{40}$ См. также: [13, p. 117]. браться до добычи, нам пришлось повернуть назад и плыть против течения, что требовало много сил» («Uns hielt allerdings die Jagd meine Kamtschadalen schossen einige Auerhähne und einen schönen Fischotter - etwas auf, da man, um das Geschossene zu bergen, häufig gegen den Strom, was sehr schwierig ist, umkehren musste») [13, p. 108]. Таким образом, путешествие часто задерживалось из-за поиска, извлечения и обработки добычи. Другой недостаток охоты был связан с тем, что для нее требовался сухой порох и свинец. И тот, и другой импортировались на Камчатку и, соответственно, были дорогими. Для защиты пороха от влаги Кегель обычно перевозил его в небольших бочках. Однако этот способ не всегда работал: кораблекрушение, пережитое Кегелем, и продолжительные дожди оставили его без пригодного для охоты пороха. В августе 1845 г. под Большерецком Кегель писал: «К сожалению, мы не могли охотиться, потому что порох был мокрым, а винтовки полностью заржавели, ибо для них не было сухого места. Весь наш рацион состоял из рыбы и чая» («Schießen war uns leider nicht möglich, weil das Pulver nass und die Gewehre ganz verrostet waren, da es keinen trockenen Ort mehr für sie gab. Unsere ganze Nahrung bestand aus Fischen und Tee») $[13, \text { p. 262 }]^{41}$.

\section{Заключение}

Подводя итог, можно сказать, что в распоряжении у Иоганна Кегеля было несколько источников пропитания. Эти источники можно разделить на три основных типа. Если он гостил в селениях, то преимущественно ел местные блюда. Эти блюда в основном готовились из рыбы, в меньшей степени из мяса, молочных продуктов, овощей и дикорастущих растений. Исследователь также употреблял предложенный ему алкоголь, но в умеренных количествах.

Кегель винил традиционно богатый на рыбу рацион жителей Камчатки в своих многочисленных проблемах со здоровьем и старался, по возможности, дополнять местную диету другими продуктами. То, что он с трудом мог добыть во время путешествий, он брал с собой. В основном это были базовые продукты питания, такие как мука, рис и соль, а также сухари, чай и сахар. Запасы чая Кегель использовал не только для собственных нужд, но и для обмена. Большую

${ }^{41}$ См. также: [13, p. 81, 265]. Значительные проблемы с поставками пороха и свинца были также наблюдались в прошлом. См., напр.: [18, p. 107-108]. 
часть он покупал у местных торговцев в Петропавловске. Они, в свою очередь, покупали чай с российских или иностранных судов, останавливавшихся на Камчатке в летние месяцы. Для поездок по безлюдным местам агроном также покупал в деревнях непортящуюся еду, обычно это была сушеная рыба и лепешки из кипрея.

Если собственных запасов или снабжения от местного населения было недостаточно, Кегель полагался на дары природы. Он собирал ягоды, дикорастущие растения, мидии и яйца или ловил рыбу. Если у него был порох и свинец, он также охотился, в основном на диких птиц и медведей. Таким образом, он мог не только обеспечить выживание в трудных условиях, но и запастись припасами для посещения поселений, где не было мяса.

Таким образом, можно сделать вывод, что Кегель был вынужден постоянно приспосабливать свой рацион к соответствующим условиям. Если в пути не было еды или была только определенная еда, исследователь дополнял ее провизией, которую брал с собой. Если она была израсходована или испорчена, он питался тем, что добывал во время охоты и сбора ягод. В путешествиях он полагался на знания и навыки местных, но также на помощь оружия и на поставки из других регионов и стран. Рацион Кегеля служит образцом того, как местные традиции дополнялись возможностям все более глобализирующегося мира - тенденция, которая продолжила развиваться ускоренными темпами и во второй половине XIX в.

\section{СПИСОК ЛИТЕРАТУРЫ}

1. Березницкий С.В. Караванная торговля России с Китаем и отечественная наука XVIII века. СПб.: МАЭ РАН, 2017.

2. Березницкий С.В. Фридрих Плениснер и его вклад в исследование коренного населения и природы Дальнего Востока России в XVIII в. // Гуманитарные исследования в Восточной Сибири и на Дальнем Востоке. 2017. № 3. С. 46-59.

3. Dahlmann, D., 2009. Sibirien. Vom 16. Jahrhundert bis zur Gegenwart. Paderborn: Schöninghl.

4. Driem, G., 2019. The tale of tea. A comprehensive history of tea from prehistoric times to the present day. Leiden; Boston: Brill.

5. Forsyth, J., 2006. A history of the peoples of Siberia: Russia's North Asian colony, 1581-1990. Cambridge: Cambridge University Press.
6. Gentes, A., 2010. Exile, murder and madness in Siberia, 1823-61. Basingstoke: Palgrave Macmillan.

7. Gibson, J.R., 1969. Feeding the Russian fur trade. Provisionment of the Okhotsk seaboard and the Kamchatka Peninsula, 1639-1856. Madison: University of Wisconsin Press.

8. Goehrke, C., 2010. Russland. Eine Strukturgeschichte. Paderborn: Schöningh.

9. Gülden, W. F., 2012. Einführung des Herausgebers. In: Kegel, J.K.E., 2012. Forschungsreise nach Kamtschatka. Reisen und Erlebnisse von 1841 bis 1847. Fürstenberg/Havel: Kulturstiftung Sibirien, pp. 11-16.

10. Hartley, J.M., 2014. Siberia. A history of the people. New Haven: Yale University Press.

11. Hildermeier, M., 2013. GeschichteRusslands. Vom Mittelalter bis zur Oktoberrevolution. München: Beck.

12. Kasten, E., 2013. Johann Karl Ehrenfried Kegel. Ein deutscher Agronom bezieht Stellung zur Land und Naturnutzung auf Kamčatka. In: Kasten, E. ed., 2013. Reisen an den Rand des Russischen Reiches. Die Wissenschaftliche Erschließung der nordpazifischen Küstengebiete im 18. und 19. Jahrhundert. Fürstenberg/Havel, pp. 207-222.

13. Kegel, J.K.E., 2012. Forschungsreise nach Kamtschatka. Reisen und Erlebnisse von 1841 bis 1847. Fürstenberg/Havel: Kulturstiftung Sibirien.

14. Krieger, M., 2009. Tee. Eine Kulturgeschichte. Köln.

15. Krusenstern, A.J. et al., 2011. Forschungsreisen auf Kamtschatka. Auszüge aus den Werken. Fürstenberg/Havel: Kulturstiftung Sibirien.

16. LeDonne, J.P., 1997. The Russian Empire and the world, 1700-1917. The geopolitics of expansion and containment. Oxford: Oxford University Press.

17. Lubrich, O., 2019. Forschen in Fürstennähe. Humboldt in Sibirien. In: Lubrich, O. ed., 2019. Die Russland-Expedition. Von der Newa bis zum Altai. München, pp. 185-204.

18. Ordubadi, D., 2013. Die Halbinsel Kamčatka in den Schriften des Leiters der ersten russischen Weltumsegelung (1803-1806) Adam Johann von Krusenstern und seines Naturforschers Georg Heinrich von Langsdorff. In: Kasten, E. ed., 2013. Reisen an den Rand des Russischen Reiches. Die Wissenschaftliche Erschließung der nordpazifischen Küstengebiete im 18. und 19. Jahrhundert. Fürstenberg/Havel: Kulturstiftung Sibirien, pp. 91-110. 
19. Pilcher, J.M., 2015. The globalization of alcohol and temperance from the gin craze to prohibition. In: Helstosky, C. ed., 2015. The Routledge history of food. New York: Routledge, pp. 156-178.

20. Pivovar, H., 2013. Carl Heinrich Mercks Forschungsarbeiten auf den Halbinseln Kamčatka und Čukotka während der Billings-SaryčevExpedition (1785-1795). In: Kasten, E. ed., 2013. Reisen an den Rand des Russischen Reiches. Die Wissenschaftliche Erschließung der nordpazifischen Küstengebiete im 18. und 19. Jahrhundert. Fürstenberg/Havel: : Kulturstiftung Sibirien, pp. 77-90.

21. Pruns, H., 2015. Europäische Zuckerwirtschaft. VII: Wiederaufstieg der Rübenzuckerindustrie in Europa 1822 bis 1849. Berlin.

22. Pruns, H., 2011. Europäische Zuckerwirtschaft. V: Der Zusammenbruch der Rübenzuckerindustrie 1814 bis 1822 . Berlin.

23. Schattenberg, S., 2008. Die korrupte Provinz? Russische Beamte im 19. Jahrhundert. Frankfurt am Main: Campus.

24. Schweizer, P., 2013. Naturforscher, Weltreisende und nationale Forschungstraditionen. Bemerkungen zur ethnologischen Erforschung Sibiriens im 18. und 19. Jahrhundert. In: Kasten, E. ed., 2013. Reisen an den Rand des Russischen Reiches. Die Wissenschaftliche Erschließung der nordpazifischen Küstengebiete im 18. und 19. Jahrhundert. Fürstenberg/Havel: Kulturstiftung Sibirien, pp. 11-28.

25. Segers, Y., 2012. Food systems in the nineteenth century. In: Bruegel, M. ed., 2012. A cultural history of food. Vol. 5. In the age of empire. London, pp. 49-66.

26. Smith, A., 2012. National cuisines. In: Pilcher, J.M. ed., 2012. The Oxford handbook of food history. New York: Oxford University Press, pp. 444-460.

27. Smith, A.F., 2015. Sugar: a global history. London: Reaktion Books.

28. Strecker, L., 2013. Friedrich Heinrich Freiherr von Kittlitz. Ein deutscher Adeliger erforscht im Dienste der Kaiserlich Russischen Akademie der Wissenschaften die Halbinsel Kamčatka. In: Kasten, E. ed., 2013. Reisen an den Rand des Russischen Reiches. Die Wissenschaftliche Erschließung der nordpazifischen Küstengebiete im 18. und 19. Jahrhundert. Fürstenberg/Havel: Kulturstiftung Sibirien, pp. 147-172.

29. Thiemer-Sachse, U., 2013. «Wir verbrachten mehr als 24 Stunden, ohne etwas anderes als
Schokolade und Limonade zu uns zu nehmen». HiN: International Review for Humbolt Studies, Vol. 14, no. 27, pp. 77-83.

30. Winkler, M., 2016. Das Imperium und die Seeotter. Die Expansion Russlands in den nordpazifischen Raum 1700-1867. Göttingen.

31. Zweynert, J., 2002. Eine Geschichte des ökonomischen Denkens in Rußland 1805-1905. Marburg.

\section{REFERENCES}

1. Bereznitskii, S.V., 2017. Karavannaya torgovlya Rossii s Kitaem i otechestvennaya nauka XVIII veka [Caravan trade between Russia and China and Russian science of the 18th century]. Sankt-Peterburg: MAE RAN. (in Russ.)

2. Bereznitskii, S.V., 2017. Fridrikh Plenisner i ego vklad $\mathrm{v}$ issledovanie korennogo naseleniya i prirody Dal'nego Vostoka Rossii v XVIII v. [Friedrich Plenisner and his contribution to the study of the indigenous population and the nature of the Russian Far East in the 18th century], Gumanitarnye issledovaniya v Vostochnoi Sibiri i na Dal'nem Vostoke, no. 3, pp. 46-59. (in Russ.)

3. Dahlmann, D., 2009. Sibirien. Vom 16. Jahrhundert bis zur Gegenwart. Paderborn: Schöninghl.

4. Driem, G., 2019. The tale of tea. A comprehensive history of tea from prehistoric times to the present day. Leiden; Boston: Brill.

5. Forsyth, J., 2006. A history of the peoples of Siberia: Russia's North Asian colony, 1581-1990. Cambridge: Cambridge University Press.

6. Gentes, A., 2010. Exile, murder and madness in Siberia, 1823-61. Basingstoke: Palgrave Macmillan.

7. Gibson, J.R., 1969. Feeding the Russian fur trade. Provisionment of the Okhotsk seaboard and the Kamchatka Peninsula, 1639-1856. Madison: University of Wisconsin Press.

8. Goehrke, C., 2010. Russland. Eine Strukturgeschichte. Paderborn: Schöningh.

9. Gülden, W. F., 2012. Einführung des Herausgebers. In: Kegel, J.K.E., 2012. Forschungsreise nach Kamtschatka. Reisen und Erlebnisse von 1841 bis 1847. Fürstenberg/Havel: Kulturstiftung Sibirien, pp. 11-16.

10. Hartley, J.M., 2014. Siberia. A history of the people. New Haven: Yale University Press.

11. Hildermeier, M., 2013. GeschichteRusslands. Vom Mittelalter bis zur Oktoberrevolution. München: Beck. 
12. Kasten, E., 2013. Johann Karl Ehrenfried Kegel. Ein deutscher Agronom bezieht Stellung zur Land und Naturnutzung auf Kamčatka. In: Kasten, E. ed., 2013. Reisen an den Rand des Russischen Reiches. Die Wissenschaftliche Erschließung der nordpazifischen Küstengebiete im 18. und 19. Jahrhundert. Fürstenberg/Havel, pp. 207-222.

13. Kegel, J.K.E., 2012. Forschungsreise nach Kamtschatka. Reisen und Erlebnisse von 1841 bis 1847. Fürstenberg/Havel: Kulturstiftung Sibirien.

14. Krieger, M., 2009. Tee. Eine Kulturgeschichte. Köln.

15. Krusenstern, A.J. et al., 2011. Forschungsreisen auf Kamtschatka. Auszüge aus den Werken. Fürstenberg/Havel: Kulturstiftung Sibirien.

16. LeDonne, J.P., 1997. The Russian Empire and the world, 1700-1917. The geopolitics of expansion and containment. Oxford: Oxford University Press.

17. Lubrich, O., 2019. Forschen in Fürstennähe. Humboldt in Sibirien. In: Lubrich, O. ed., 2019. Die Russland-Expedition. Von der Newa bis zum Altai. München, pp. 185-204.

18. Ordubadi, D., 2013. Die Halbinsel Kamčatka in den Schriften des Leiters der ersten russischen Weltumsegelung (1803-1806) Adam Johann von Krusenstern und seines Naturforschers Georg Heinrich von Langsdorff. In: Kasten, E. ed., 2013. Reisen an den Rand des Russischen Reiches. Die Wissenschaftliche Erschließung der nordpazifischen Küstengebiete im 18. und 19. Jahrhundert. Fürstenberg/Havel: Kulturstiftung Sibirien, pp. 91-110.

19. Pilcher, J.M., 2015. The globalization of alcohol and temperance from the gin craze to prohibition. In: Helstosky, C. ed., 2015. The Routledge history of food. New York: Routledge, pp. 156-178.

20. Pivovar, H., 2013. Carl Heinrich Mercks Forschungsarbeiten auf den Halbinseln Kamčatka und Čukotka während der Billings-SaryčevExpedition (1785-1795). In: Kasten, E. ed., 2013. Reisen an den Rand des Russischen Reiches. Die Wissenschaftliche Erschließung der nordpazifischen Küstengebiete im 18. und 19. Jahrhundert. Fürstenberg/Havel: : Kulturstiftung Sibirien, pp. 77-90.
21. Pruns, H., 2015. Europäische Zuckerwirtschaft. VII: Wiederaufstieg der Rübenzuckerindustrie in Europa 1822 bis 1849. Berlin.

22. Pruns, H., 2011. Europäische Zuckerwirtschaft. V: Der Zusammenbruch der Rübenzuckerindustrie 1814 bis 1822 . Berlin.

23. Schattenberg, S., 2008. Die korrupte Provinz? Russische Beamte im 19. Jahrhundert. Frankfurt am Main: Campus.

24. Schweizer, P., 2013. Naturforscher, Weltreisende und nationale Forschungstraditionen. Bemerkungen zur ethnologischen Erforschung Sibiriens im 18. und 19. Jahrhundert. In: Kasten, E. ed., 2013. Reisen an den Rand des Russischen Reiches. Die Wissenschaftliche Erschließung der nordpazifischen Küstengebiete im 18. und 19. Jahrhundert. Fürstenberg/Havel: Kulturstiftung Sibirien, pp. 11-28.

25. Segers, Y., 2012. Food systems in the nineteenth century. In: Bruegel, M. ed., 2012. A cultural history of food. Vol. 5. In the age of empire. London, pp. 49-66.

26. Smith, A., 2012. National cuisines. In: Pilcher, J.M. ed., 2012. The Oxford handbook of food history. New York: Oxford University Press, pp. $444-460$

27. Smith, A.F., 2015. Sugar: a global history. London: Reaktion Books.

28. Strecker,L., 2013. Friedrich Heinrich Freiherr von Kittlitz. Ein deutscher Adeliger erforscht im Dienste der Kaiserlich Russischen Akademie der Wissenschaften die Halbinsel Kamčatka. In: Kasten, E. ed., 2013. Reisen an den Rand des Russischen Reiches. Die Wissenschaftliche Erschließung der nordpazifischen Küstengebiete im 18. und 19. Jahrhundert. Fürstenberg/Havel: Kulturstiftung Sibirien, pp. 147-172.

29. Thiemer-Sachse, U., 2013. «Wir verbrachten mehr als 24 Stunden, ohne etwas anderes als Schokolade und Limonade zu uns zu nehmen». HiN: International Review for Humbolt Studies, Vol. 14 , no. 27 , pp. $77-83$.

30. Winkler, M., 2016. Das Imperium und die Seeotter. Die Expansion Russlands in den nordpazifischen Raum 1700-1867. Göttingen.

31. Zweynert, J., 2002. Eine Geschichte des ökonomischen Denkens in Rußland 1805-1905. Marburg.

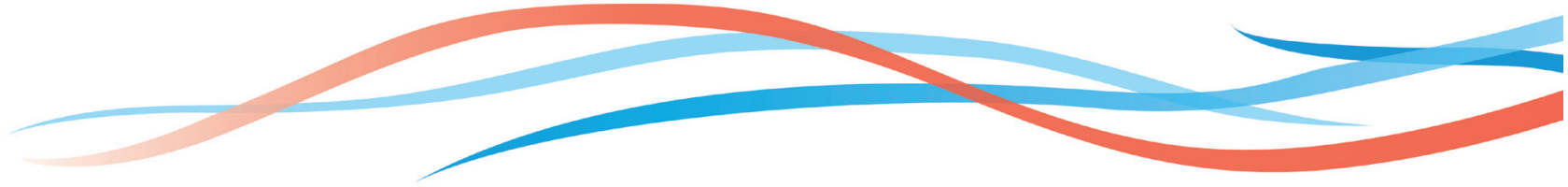

